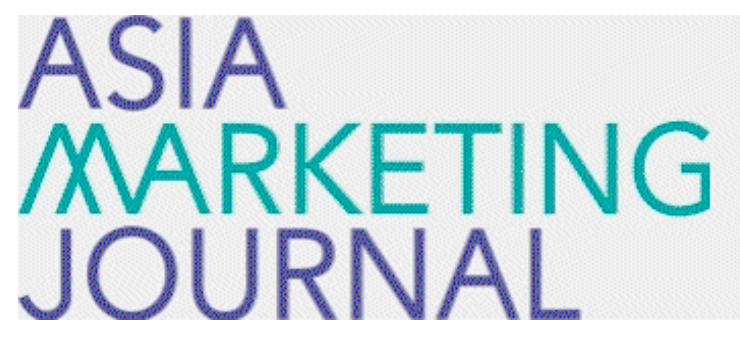

ASIA MARKETING JOURNAL

Volume 17 | Issue 4

Article 7

$1-31-2016$

\title{
ASIA MARKETING JOURNAL 제17권 제4호 목차
}

Follow this and additional works at: https://amj.kma.re.kr/journal

Part of the Marketing Commons

\section{Recommended Citation}

(2016) "ASIA MARKETING JOURNAL 제17권 제4호 목차," Asia Marketing Journal: Vol. 17 : Iss. 4 , Article 7.

Available at: https://doi.org/10.53728/2765-6500.1415

This Article is brought to you for free and open access by Asia Marketing Journal. It has been accepted for inclusion in Asia Marketing Journal by an authorized editor of Asia Marketing Journal. 


\section{ASAMARREETNG JOUNMAL Special Issue for the International Conference of Marketing Associations 2015: Marketing Research in Asia}

\section{Vol. 17 No. 04 January 2016}

\section{$<$ Research Note $>$}

The Past, Present, and Future of Marketing Research in Asia

\section{$<$ Research Paper $>$}

Can Threatened Moral Self Make People Prefer Ecological Product?

- An Eye Tracking Research based on Chinese Face Consciousness

Solving the Mystery of Consistent Negative/Low Net Promoter Score (NPS)

in Cross-Cultural Marketing Research

Sanjay Seth - Don Scott - Chad Svihel - Stephen Murphy-Shigematsu

K-Pop Music Worldwide and Digital Marketing Role in Brazil

Distribution Channel, Matching, and Welfare Asymmetry in the

Korean Insurance Industry: A Hint from Matching Theory

A Study on the Interaction between Corporate Reputation and Negativity Framing on Consumer Evaluation of Corporate Social Responsibility 